\title{
Identifikasi Bakteri dan Efektivitas Antibiotik dalam Pengencer untuk Mengontrol Pertumbuhan Bakteri pada Semen Sapi Friesian Holstein
}

\author{
(BACTERIAL IDENTIFICATION AND EFFICACY OF ANTIBIOTICS IN EXTENDER \\ FOR CONTROLLING THE GROWH OF BACTERIA IN FRIESIAN HOSLTEIN SEMEN) \\ Muttaqinullah Rabusin ${ }^{1}$, Andriani ${ }^{2}$, \\ Raden Iis Arifiantini ${ }^{3}$, Ni Wayan Kurniani Karja ${ }^{3}$ \\ ${ }^{1}$ Program Studi Biologi Reproduksi, \\ ${ }^{2}$ Balai Besar Penelitian Veteriner, Bogor, \\ ${ }^{3}$ Bagian Reproduksi dan Kebidanan, \\ Departemen Klinik Reproduksi dan Patologi, \\ Fakultas Kedokteran Hewan, Institut Pertanian Bogor, \\ Jln. Agatis, Kampus IPB Dramaga, Bogor, Jawa Barat, Indonesia 16680, \\ E-mail: karjanwk13@gmail.com
}

\begin{abstract}
Abstrak
Penelitian ini dilakukan untuk mengidentifikasi bakteri di dalam semen segar sapi Friesian Holstein (FH) dan menguji efektivitas kombinasi antibiotik penisilin dan streptomisin (PS) atau gentamisin, tilosin, linkomisin, dan spektinomisin (GTLS) di dalam pengencer semen terhadap perkembangan bakteri. Penelitian ini dilakukan dalam tiga tahap. Tahap 1, dilakukan identifikasi bakteri dalam semen segar segera setelah koleksi. Tahap 2, dilakukan identifikasi bakteri pada pengencer yang digunakan untuk pembekuan semen. Tahap 3, dilakukan identifikasi bakteri dalam semen beku. Dalam penelitian ini berhasil ditemukan tiga jenis bakteri dalam semen segar, yaitu Klebsiella sp., Micrococcus sp., dan Pediococcus sp. Tiga jenis bakteri ditemukan di dalam pengencer semen, yaitu Enterobacter cloacae, Pseudomonas diminuta dan Serratia plymutica dan dua jenis bakteri ditemukan di dalam semen beku, yaitu Enterobacter cloacae dan Serratia plymutica. Dari data tersebut dapat disimpulkan ditemukan bakteri yang umum terdapat pada lingkungan dan antibiotik PS dan GTLS mempunyai efektifitas yang sama dalam menghambat pertumbuhan bakteri dan tidak memengaruhi kualitas semen
\end{abstract}

Kata-kata kunci: bakteri; antibotik pengencer; semen sapi

\begin{abstract}
This study was designed to investigate the presence of bacterial species in Friesian Holstein (FH) bovine semen at the time of collection, processing and to assess the efficacy of two types of antibiotics combinations; penicillin and streptomycin (PS) and gentamycin, tylosin, lincomycin and spectinomycin (GTLS) in semen extender on bacterial control and quality of semen. For this purpose, three experiments were conducted. In experiment 1 , identification of bacterial content in fresh semen which collected from 5 bovine ejaculates. In experiment 2 , identification of bacterial content in skimmilk-eggyolk extender which were prepared in artificial insemination center, Lembang, Bandung. In experiment 3, identification of bacterial content in frozen thawed semen. In the result, some of bacterial species were isolated from the bovine semen. The GTLS combination of antibiotics may be incorporated into a freezing extender or protocol without compromising the post-thawed semen quality of FH bull spermatozoa. Three types of bacteria were found in fresh semen; Klebsiella sp., Micrococcus sp., and Pediococcus sp.. Three types of bacteria were found in semen extender; Enterobacter cloacae, Pseudomonas diminuta and Serratia plymutica. Two types of bacteria were found in frozen semen; Enterobacter cloacae and Serratia plymutica. In conclusion, antibiotics PS and GTLS were effective for controlling the growth of bacteria in frozen semen.
\end{abstract}

Keywords: bacterial species; bovine semen; extender; antibiotic 


\section{PENDAHULUAN}

Semen terdiri atas spermatozoa dan plasma semen yang diejakulasikan hewan jantan dan dapat digunakan untuk proses pembuahan. Semen yang dimaksud adalah semen dari hewan jantan unggul sebagaimana disebutkan dalam Standar Nasional Indonesia (SNI) 2017 Tentang Semen Beku Sapi (BSN 2017). Semen merupakan media yang mengandung nutrisi dan protein sehingga ideal bagi pertumbuhan mikroorganisme (Martin et al., 2010). Beberapa bakteri patogen serta bakteri saprophytic juga dapat mengontaminasi semen sapi (Gloria et al., 2014). Bakteri yang terdapat dalam semen dapat bersumber dari testis, kelenjar aksessoris, vas deferens, urethra, preputium atau penis (Thibier dan Guerin, 2000).

Mikroorganisme memberikan efek buruk secara langsung pada fungsi reproduksi, di antaranya menyebabkan agglutinasi spermatozoa, mengurangi kemampuan reaksi akrosom, merusak morfologi spermatozoa dan deoxyribonucleid acid (DNA) integrity spermatozoa (Moretti et al., 2009; GonzálezMarín et al., 2011). Kontaminasi mikroorganisme juga dapat terjadi selama pengolahan semen menjadi semen beku. Semen beku yang digunakan untuk IB apabila terkontaminasi oleh mikroorganisme dalam jumlah di atas 5000 colony form unit (cfu) per mililiter dapat menyebabkan penurunan angka kebuntingan dan penyebaran penyakit pada sapi betina (Thibier dan Guerin, 2000). Beberapa bakteri yang umum ditemukan pada semen sapi yaitu Escherichia, Staphylococcus, Campylobacter, Pseudomonas, Acinetobacter dan Citrobacter (Shin et al., 1988; Abro et al., 2016).

Bakteri yang terkandung dalam semen dapat dikontrol dan dihambat pertumbuhannya dengan pemberian antibiotik (Gloria et al., 2014). Antibiotik yang digunakan dalam produksi semen beku di Balai Inseminasi Buatan (BIB) di seluruh Indonesia hingga saat ini adalah kombinasi antibiotik penisilin dan streptomisin (PS). Banyak antibiotik yang telah diteliti baik dosis, metode pemberian, dan interaksinya dengan pengencer. Kombinasi antibiotik yang lebih efisien telah dikembangkan oleh Shin et al. (1988) yaitu gentamisin, tilosin, linkomisin, dan spektinomisin (GTLS) yang telah digunakan secara luas di Amerika dan Eropa (Morrell dan Wallgren, 2014). Pengencer semen beku komersial yang beredar luas di berbagai negara telah menggunakan jenis antibiotik GTLS.
Balai IB nasional yang ada di Indonesia sejak tahun 2013 telah mengekspor semen beku ke Malaysia, Myanmar, Kamboja, Afganistan, Kirgystan, dan Kazakhstan (DJPKH 2015). Mengacu pada ketentuan dunia internasional, perlu dilakukan kajian terhadap penggunaan jenis antibitik yang dapat diterima oleh dunia internasional sehingga produk semen beku Indonesia dapat bersaing dan berkembang secara global. Penelitian mengenai isolasi dan identifikasi bakteri pada produksi semen sapi di Indonesia masih jarang dilakukan, sehingga sulit mendapatkan informasi atau data mengenai jenis bakteri dalam semen. Oleh karena itu, penelitian in bertujuan untuk mengidentifikasi kandungan bakteri dalam semen sapi dan kombinasi serta antibiotik alternatif yang tepat untuk mengontrol bakteri, sehingga menghasilkan semen beku sapi yang berkualitas, aman dan bebas dari penyakit.

\section{METODE PENELITIAN}

Penelitian dilakukan dalam tiga tahap. Tahap 1, dilakukan identifikasi bakteri dalam semen segar segera setelah koleksi. Tahap 2, dilakukan identifikasi bakteri pada pengencer yang digunakan untuk pembekuan semen. Tahap 3, dilakukan identifikasi bakteri dalam semen beku. Koleksi semen dilakukan pada lima ekor pejantan sapi FH di BIB Lembang, Bandung, Jawa Barat. Semen dikoleksi dengan vagina buatan yang telah disterilkan dan sapi pejantan digunakan sebagai teaser (pengusik). Prosedur koleksi semen dilakukan sesuai standard operating procedure (SOP) BIB Lembang. Sampel semen yang dikoleksi, dari vagina buatan dimasukkan ke dalam tabung steril, disimpan di dalam cold box suhu $4^{\circ} \mathrm{C}$ kemudian dibawa ke laboratorium bakteriologi Balai Besar Penelitian Veteriner (Bbalitvet) Bogor untuk dilakukan isolasi, identifikasi dan penghitungan jumlah koloni bakteri.

Isolasi, identifikasi dan penghitungan jumlah koloni bakteri dilakukan dengan mengacu pada SNI 2897: 2008. Sebanyak 200 $\mu \mathrm{L}$ sampel semen dimasukkan ke dalam media cair Brain Heart Infusion Broth (BHI) dan diinkubasikan pada suhu $37^{\circ} \mathrm{C}$ selama 24 jam, kemudian diinokulasikan pada permukaan media selektif Mac Conkey Agar _ (MCA) dan Eosin Metylene Blue (EMB) agar untuk isolasi dan identifikasi bakteri Gram negatif, sedangkan media Blood Agar (BA) untuk bakteri gram positif. Media selektif agar yang telah diinokulasi 
selanjutnya diinkubasikan pada suhu $37^{\circ} \mathrm{C}$ selama 24-48 jam dengan posisi cawan Petri terbalik. Isolasi dan identifikasi Campylobacter sp. dilakukan dengan memasukkan $200 \mu \mathrm{L}$ sampel semen ke dalam media cair Nutrient Broth No. 2 (NB No. 2, Oxoid) yang telah ditambahkan growth supplement (Oxoid SR 232E), kemudian diinkubasikan pada suhu $42^{\circ} \mathrm{C}$ dalam kondisi mikroaerofilik $\left(5 \% \mathrm{O}_{2}, 10 \% \mathrm{CO}_{2}\right.$, $85 \% \mathrm{~N}_{2}$ ). Inkubasi dilakukan menggunakan jar yang telah diisi CampyGen (Oxoid). Selanjutnya kultur diinokulasikan pada media CCDA yang mengandung CCDA selective supplement (Oxoid SR 155E) dan diinukasikan kembali pada suhu $42^{\circ} \mathrm{C}$ pada kondisi mikroaerofilik seperti tersebut selama 24-48 jam. Identifikasi bakteri dari media agar selektif (MCA, BA, EMB dan CCDA) dilakukan dengan uji motilitas, pewarnaan Gram, uji katalase dan oksidase, uji terhadap gula-gula.

Penghitungan jumlah bakteri dilakukan dengan cara sebanyak $200 \mu \mathrm{L}$ sampel semen dimasukkan ke dalam buffer saline dan dilakukan pengenceran secara bertingkat. Selanjutnya sebanyak $100 \mu \mathrm{L}$ dimasukkan ke dalam cawan Petri steril kemudian ditambahkan media plate count agar (PCA) sebanyak $15 \mathrm{~mL}$ yang telah dihangatkan pada suhu $44 \pm 2^{\circ} \mathrm{C}$ kemudian dihomogenkan dan disimpan pada suhu ruang hingga agar memadat. Setelah agar memadat, cawan Petri yang telah berisi inoculum diinkubasikan pada suhu $37^{\circ} \mathrm{C}$ selama 24 jam. Kemudian jumlah koloni bakteri yang tumbuh dihitung.

Tahap kedua dari penelitian ini adalah isolasi dan identifikasi bakteri dalam pengencer sebelum digunakan. Pengencer yang digunakan dalam penelitian ini adalah pengencer skim kuning telur yang rutin digunakan di Balai IB Lembang, yaitu pengencer. Pengencer semen tersebut kemudian dibagi dalam tiga kelompok (Tabel 1) yaitu; kelompok P-AB (-) pengencer tanpa antibiotik, P-AB (PS) dengan kombinasi antibiotik penisilin dan streptomisin, dan kelompok P-AB (GTLS) dengan kombinasi antibiotik gentamisin, tilosin, linkomisin dan spektinomisin menggunakan metode BIB Lembang dan Shin et al. (1988). Sebanyak lima mililiter dari masing-masing pengencer kemudian disimpan di dalam cold box (suhu 4 ${ }^{\circ} \mathrm{C}$ ) dan dibawa ke laboratorium bakteriologi BBLITVET Bogor untuk diproses lebih lanjut. Isolasi, identifikasi, dan penghitungan jumlah koloni bakteri pada pengencer dilakukan sama dengan tahap pertama.
Tahap ketiga dilakukan untuk identifikasi bakteri dalam semen beku dan untuk melihat efektivitas antibiotik terhadap pertumbuhan bakteri dalam semen. Koleksi semen dilakukan seperti pada tahap satu dari penelitian. Semen yang dikoleksi segera diamati sesuai SOP di BIB Lembang. Pengamatan dilakukan secara makroskopik dan mikroskopik. Pengamatan makroskopik meliputi volume, warna, konsistensi, dan $\mathrm{pH}$. Pengamatan mikroskopik yaitu gerakan massa, persentase spermatozoa motil (\%), dan konsentrasi spermatozoa (juta $\mathrm{mL}$ $\left.{ }^{1}\right)$. Semen selanjutnya dibagi tiga, masingmasing diencer dengan pengencer skim kuning telur sesuai dengan tahap kedua. Semen yang sudah dicampurkan ke dalam bahan pengencer, dikemas dalam straw 0,25 mL (Minitube Jerman) menggunakan mesin otomatis (Combo System Minitube Jerman) dengan konsentrasi $25 \times 10^{6}$ spermatozoa per straw. Semen dalam straw diekuilibrasi pada suhu $4{ }^{\circ} \mathrm{C}$ selama 4 jam. Pembekuan semen dilakukan menggunakan mesin otomatis (Digit Cool 5300 ZB 250 IMV Prancis) selama 9 menit. Mesin diprogram dengan laju penurunan $3{ }^{\circ} \mathrm{C}$ per menit dari suhu $+4{ }^{\circ} \mathrm{C}$ ke $-10^{\circ} \mathrm{C}, 40^{\circ} \mathrm{C}$ per menit dari suhu -10 ${ }^{\circ} \mathrm{C}$ ke $-100{ }^{\circ} \mathrm{C}$ dan $20^{\circ} \mathrm{C}$ per menit dari suhu $100^{\circ} \mathrm{C}$ ke $-140^{\circ} \mathrm{C}$. Semen yang telah dibekukan dimasukkan ke dalam $\mathrm{N}_{2}$ cair suhu $-196{ }^{\circ} \mathrm{C}$ dalam kontainer $\mathrm{N}_{2}$ cair.

Sampel semen beku dibawa ke laboratorium bakteriologi BBLITVET Bogor untuk dilakukan isolasi dan identifikasi bakteri. Straw di-thawing pada suhu $37^{\circ} \mathrm{C}$, selama 30 detik. Isolasi, identifikasi, dan penghitungan jumlah koloni bakteri pada semen beku dilakukan sama dengan tahap pertama. Data jenis dan jumlah bakteri yang diperoleh disajikan secara deskriptif.

\section{HASIL DAN PEMBAHASAN}

Hasil pemeriksaan sampel yang dilakukan, tidak ditemukan bakteri E. coli, Pseudomonas, Stapylococcus, Streptococcus, dan Camphylobacter pada semen segar. Bakteri Klebsiella sp. ditemukan tumbuh pada MCA. Bakteri Micrococcus sp. dan Pediococcus sp. ditemukan pada media BA. Jumlah koloni bakteri atau total plate count (TPC) pada kelima semen segar, paling tinggi ditemukan pada semen segar dari sapi no. 1 sebanyak $1,04 \times 10^{2}$ colony form unit (cfu)/mL. Bakteri Klebsiella sp., Micrococcus sp., dan Pediococcus sp., ditemukan pada sapi no. 1 tersebut. Sebanyak $8.00 \times 10^{1} \mathrm{cfu} / \mathrm{mL}$ koloni 
bakteri ditemukan pada sapi no. 2. Dua ekor sapi yaitu no. 3 dan 5 memiliki jumlah bakteri yang sama yaitu $1.00 \times 10^{1} \mathrm{cfu} / \mathrm{mL}$, namun memiliki jenis bakteri yang berbeda, masingmasing sampel ditemukan bakteri Micrococcus sp., dan Pediococcus sp.. Semen segar dari sapi no. 4 tidak ditemukan koloni bakteri yang tumbuh.

Informasi mengenai bakteri dalam semen hewan ternak di Indonesia masih terbatas. Publikasi mengenai keberadaan bakteri di dalam semen pernah dilaporkan tahun 1985 oleh Poeloengan (1985). Sebanyak 11 bakteri dilaporkan dalam publikasi tersebut yaitu Staphylococcus epidermidis, Staphylococcus aureus, Nocardia, Acinetobacter, Alkaligenes, Citrobacter, Pseudomonas, Crhomobacterium, Micrococcus, Corynebacterium, dan Proteus. Peraturan Menteri Pertanian Republik Indonesia Nomor 10/Permentan/PK.210/3/2016 (Kementan 2016), tentang Penyediaan dan Peredaran Semen Beku Ternak Ruminansia disebutkan bahwa semen beku ternak ruminansia yang diedarkan harus memenuhi persyaratan kesehatan hewan pejantan unggul dan bebas penyakit anthraks, brucellosis (Brucella abortus), Bovine Viral Diarrhea (BVD), Septicaemia epizootical (haemorrhagic septicaemia), Infectious Bovine Rhinotracheitis, Enzootic Bovine Leucosis (EBL), Bovine Tuberculosis, Paratuberculosis, Leptospirosis, Camphylobacteriosis, Trichomoniasis, dan penyakit jembrana untuk sapi bali.

Dalam penelitian ini tidak ditemukan bakteri patogen di dalam semen segar. Hal ini karena manajemen kesehatan hewan dan produksi semen di Balai IB sudah baik, sehingga kondisi kesehatan sapi pejantan tetap terkontrol. Bakteri yang ditemukan dalam semen segar adalah bakteri yang umum ditemukan pada lingkungan yang mungkin mencemari peralatan, dan atau proses penampungan sampai pembekuan semen.

Bakteri Gram negatif dicirikan dengan koloni mukoid, berbentuk batang, tidak motil, begitu pula dalam Voges Proskaüer (VP) test hasilnya negatif, katalase positif, oksidase negatif diidentifikasikan sebagai bakteri Klebsiella sp. Bakteri Gram positif yang berbentuk kokus, non motile, non sporing, aerobik, katalase positif, oksidase positif diidentifikasikan sebagai bakteri Micrococcus sp., sedangkan yang berbentuk kokus yang berpasangan dua atau empat, katalase positif, oksidase negatif diidentifikasikan sebagai bakteri Pediococcus sp. (Cowan et al., 1993).

Bakteri Klebsiella sp. merupakan bakteri yang umum ditemukan di lingkungan, air, tanah, dan tanaman. Bakteri Klebsiella sp. pada hewan, dapat menyerang tubuh ketika kondisi pertahanan tubuh menurun. Bakteri Klebsiella sp. pada semen merupakan bacteriospermia yang dapat memengaruhi kualitas semen (Ibadin dan Ibeh 2008). Bakteri Micrococcus sp. merupakan bakteri yang mirip dengan staphylococci dan mudah ditemukan pada lingkungan dan jarang berhubungan dengan penyakit. Brown et al. (1974) juga melaporkan di dalam penelitiannya telah ditemukan bakteri Micrococcus sp. di dalam semen segar sapi. Andrabi et al. (2016) melaporkan terdapat bakteri Micrococcus sp. di dalam semen segar kerbau. Pediococcus sp. pada ternak merupakan microbial flora normal dan dapat ditemukan di dalam feses (Fuquay et al. 2011).

Jumlah koloni bakteri yang didapatkan dalam penelitian ini jumlah yang paling tinggi sebesar $1,04 \times 10^{2} \mathrm{cfu} / \mathrm{mL}$. Poeloengan (1985) melaporkan jumlah koloni bakteri semen segar sapi sebesar $1,00 \times 10^{2}$ sampai dengan $3,60 \times$ $10^{5}$. Brown et al. (1974) melaporkan hasil penelitiannya bahwa jumlah koloni bakteri semen segar sapi $\mathrm{FH}$ adalah $2,00 \times 10^{2}$ sampai dengan 5,34 × $10^{5}$. Sannat et al. (2015) melaporkan bahwa jumlah koloni bakteri pada semen segar sapi yaitu sebesar $2,36 \times 10^{4} \mathrm{cfu} /$ $\mathrm{mL}$. Sementara itu Patel et al. (2011) melaporkan ditemukannya koloni bakteri pada semen sapi Guernsey, FH, dan Jersey masingmasing $2_{2} .6 \times 10^{5_{-}}, 1_{2} .3 \times 10^{5}$, dan $5_{2}-3 \times 10^{4} \mathrm{cfu} /$ $\mathrm{mL}$. Berbedanya jumlah koloni bakteri, kemungkinan dapat dipengaruhi oleh lingkungan, kebersihan petugas dan alat koleksi semen yang digunakan serta dapat dipengaruhi oleh breed (Patel et al., 2011). Perumal et al. (2013) menyatakan bahwa lubang preputium dapat menjadi sumber utama dari berbagai jenis bakteri yang berasal dari tanah, bedding, dan feses.

Pengencer semen yang digunakan dalam penelitian ini adalah skim kuning telur. Pengencer dibagi tiga kelompok yaitu pengencer tanpa antibiotik (P-AB (-), pengencer dengan menggunakan antibiotik penisilin dan streptomisin (P-AB (PS), dan pengencer dengan menggunakan antibiotik gentamisin, tilosin, linkomisin, dan spektinomisin P-AB (GTLS). Ketiga kelompok pengencer semen ditanam pada berbagai media agar untuk menumbuhkan 
Tabel 1. Jenis dan dosis antibiotik dalam media pengencer

\begin{tabular}{lll}
\hline Kelompok & Antibiotik & Dosis \\
\hline P-AB (-) P-AB (PS)* & Tanpa antibiotikPenisilin $\left(\mathrm{IU} \mathrm{mL}^{-1}\right)$ & -1000 \\
& Streptomisin $\left(\mathrm{mg} \mathrm{mL}^{-1}\right)$ & 1 \\
P-AB (GTLS)** & Gentamisin $\left.(\mu \mathrm{g} \mathrm{mL})^{-1}\right)$ & 500 \\
& Tilosin $\left.(\mu \mathrm{g} \mathrm{mL})^{-1}\right)$ & 100 \\
& Linkomisin $\left.(\mu \mathrm{g} \mathrm{mL})^{-1}\right)$ & 300 \\
& Spektinomisin $\left(\mu \mathrm{gL}^{-1}\right)$ & 600 \\
\hline
\end{tabular}

Keterangan: kelompok P-AB (-) pengencer tanpa antibiotik, P-AB (PS) dengan kombinasi antibiotik penisilin dan streptomisin, dan kelompok P-AB (GTLS) dengan kombinasi antibiotik gentamisin, tilosin, linkomisin dan spektinomisin. ${ }^{*}$ BIB Lembang, ${ }^{* *}$ Shin et al. (1988)

Tabel 2. Jenis bakteri dan jumlah koloni bakteri di dalam pengencer

\begin{tabular}{llll}
\hline No & Pengencer & Jumlah bakteri $(\mathrm{cfu} / \mathrm{mL})$ & Jenis bakteri \\
\hline 1 & P-AB (-) & $5,12 \times 10^{3}$ & $\begin{array}{l}\text { Enterobacter cloacae, } \\
\text { Pseudomonas diminuta } \text { dan }\end{array}$ \\
& & & Serratia plymutica \\
2 & P-AB (PS) & $1,22 \times 10^{3}$ & Serratia plymutica \\
3 & P-AB(GTLS) & $8,30 \times 10^{2}$ & Enterobacter cloacae \\
\hline
\end{tabular}

Keterangan:P-AB $(-)=$ Pengencer tanpa antibiotik, $\mathrm{P}-\mathrm{AB}(\mathrm{PS})=$ Pengencer dengan antibiotik penisilin dan streptomisin, P-AB (GTLS) = Pengencer dengan antibiotik gentamisin, tilosin, linkomisin, dan spektinomisin

Tabel 3. Jenis bakteri dan jumlah koloni bakteri di dalam semen beku

\begin{tabular}{llll}
\hline No & Semen beku & Jumlah bakteri (cfu/mL) & Jenis bakteri (n sapi) \\
\hline 1 & P-AB (-) & $7.76 \times 10^{3}$ & $\begin{array}{l}\text { Enterobacter cloacae }(4) \\
\text { Serratia plymutica }(1)\end{array}$ \\
& & & Enterobacter cloacae (5) \\
3 & P-AB (PS) & $7.10 \times 10^{2}$ & Enterobacter cloacae (5) \\
\hline
\end{tabular}

Keterangan: P-AB (-) = Pengencer tanpa antibiotik, $\mathrm{P}-\mathrm{AB}(\mathrm{PS})=$ Pengencer dengan antibiotik penisilin dan streptomisin, P-AB $($ GTLS $)=$ Pengencer dengan antibiotik gentamisin, tilosin, linkomisin, dan spektinomisin

bakteri E. coli, Pseudomonas, Stapylococcus, Streptococcus, dan Camphylobacter. Bakteri yang ditemukan adalah Pseudomonas, namun empat bakteri lainnya tidak ditemukan. Ditemukan bakteri jenis lain yaitu bakteri Enterobacter cloacae dan Serratia plymutica. Pengencer P-AB (-) ditemukan adanya pertumbuhan bakteri Enterobacter cloacae, Pseudomonas diminuta dan Serratia plymutica. Pengencer P-AB (PS) hanya ditemukan bakteri Serratia plymutica dan pada pengencer P-AB (GTLS) ditemukan bakteri Enterobacter cloacae. Pengamatan terhadap media PCA diketahui jumlah koloni bakteri dalam pengencer. Jumlah koloni bakteri pada pengencer $\mathrm{P}-\mathrm{AB}(-)$ yaitu sebanyak $5,12 \times 10^{3}$ $\mathrm{cfu} / \mathrm{mL}$. Jumlah koloni pada pengencer P-AB (PS) ditemukan koloni sebanyak 1,22 × $10^{3} \mathrm{cfu} /$ $\mathrm{mL}$, dan pengencer P-AB (GTLS) ditemukan koloni sebanyak $8,30 \times 10^{2} \mathrm{cfu} / \mathrm{mL}$. Pertumbuhan jenis bakteri dan jumlah koloni bakteri di dalam pengencer disajikan pada Tabel 2 .

Keberadaan bakteri pada pengencer semen di Indonesia masih sulit ditemukan. Laporan Hoyos-Marulanda et al. (2017) pada pengencer semen sapi ditemukan berbagai jenis bakteri 
seperti E. coli, Enterobacter aerogenes, Staphylococcus aureus, Staphylococcus warneri, Staphylococcus simulans, Staphylococcus sciuri, Staphylococcus capitis, Rhizobium radiobacter, Enterococcus faecalis, Leuconostoc mesenteroides ssp. cremoris, Sphigomonas paucimobilis, Aeromonas salmonicidae, Aerococcus viridans.

Qadeer et al. (2013) meneliti bakteri dalam pengencer Tris asam sitrat ditemukan jumlah koloni bakteri sebanyak 3,00 × $10^{3}$ sampai dengan $15,00 \times 10^{3} \mathrm{cfu} / \mathrm{mL}$ tanpa menyebutkan jenis bakteri yang ditemukan di dalam pengencer tersebut. Meena et al. (2015) melaporkan dalam pengencer Tris kuning telur memiliki jumlah koloni bakteri dengan nilai rataan yaitu $3,80 \times$ $10^{2} \mathrm{cfu} / \mathrm{mL}$ juga tidak menyebutkan jenis bakteri yang ditemukan. Penelitian Akhter et al. (2013) menggunakan PS dalam pengencer Tris asam sitrat ditemukan jumlah koloni bakteri 7,00 $\times 10^{2}$. Keberadaan bakteri di dalam pengencer semen bisa terjadi akibat kontaminasi saat proses pembuatan pengencer, karena dalam pengencer memiliki nutrisi bagi pertumbuhan mikroorganisme (Morrel 2014).

Bakteri enterobacter adalah bakteri Gram negatif, bentuk batang, motil, aerobik dan anaerobik fakultatif, katalase positif, oksidase negatif, memecah fermentasi gula, memproduksi gas, VP positif, gluconate positif, gelatin mencair dengan perlahan, dan memproduksi ornithine decarboxylase (Cowan et al., 1993). Kemudian bakteri Pseudomonas merupakan Gram negatif, bentuk batang, motil (dengan flagella polar), aerobik, katalase positif, oksidase positif, memecah gula dengan oxidasi, fluorescent, dapat mendifusi pigment kuning pada beberapa spesies. Bakteri Serratia adalah bakteri Gram negatif, bantuk batang, motil, aerobik dan anaerobik fakultatif, katalase positif, oxidase negatif, memecah fermentasi gula, sering menghasilkan gas pada beberapa spesies, umumnya VP positif, gluconate positif, beberapa spesies menghasilkan ornithin decarboxylase, deoxyribonuclease positif, beberapa spesies menghasilkan pigment merah saat tumbuh di media (Cowan et al., 1993). Ketiga bakteri yang ditemukan merupakan tidak tergolong bakteri patogen dan banyak terdapat di lingkungan, kemungkinan bakteri yang ada di dalam pengencer bersumber dari lingkungan dan alat yang digunakan pada saat pembuatan bahan pengencer.
Semen beku yang telah di-thawing dilakukan uji identifikasi bakteri. Semen beku ditanam di berbagai media agar seperti pada tahap pertama. Hasil evaluasi bakteri pada semen beku, tidak ditemukan bakteri $E$. coli, Pseudomonas, Stapylococcus, Streptococcus, dan Camphylobacter, akan tetapi ditemukan bakteri jenis lain yaitu bakteri Enterobacter cloacae dan Serratia plymutica. Semen beku dalam pengencer P-AB (-) memiliki jumlah koloni bakteri $7,76 \times 10^{3} \mathrm{cfu} / \mathrm{mL}$ dan ditemukan bakteri Enterobacter cloacae (ditemukan pada empat ekor sapi) dan bakteri Serratia plymutica (ditemukan pada satu ekor sapi). Semen beku dari pengencer P-AB (PS) memiliki jumlah koloni bakteri $7,10 \times 10^{2} \mathrm{cfu} / \mathrm{mL}$ dan ditemukan bakteri Enterobacter cloacae (ditemukan pada lima ekor sapi). Selanjutnya kelompok semen beku dari pengencer P-AB (GTLS) memiliki jumlah koloni bakteri sebanyak 4,90 × $10^{2} \mathrm{cfu} /$ $\mathrm{mL}$ dan ditemukan bakteri Enterobacter cloacae (ditemukan pada lima ekor sapi). Hasil pertumbuhan jenis bakteri dan jumlah koloni bakteri di dalam pengencer disajikan pada Tabel 3.

Najee et al., (2012) melaporkan telah ditemukan bakteri Stenotrophomonas maltophilia dan Pseudomonas aeroginosa di dalam semen beku sapi. Berbedanya jenis bakteri yang ditemukan kemungkinan akibat pengaruh lingkungan dan peralatan yang digunakan dalam produksi semen beku. Patel et al, (2012) melaporkan jumlah koloni bakteri semen beku sapi FH 1,62 × $10^{2} \mathrm{cfu} / \mathrm{mL}$. Namun, pada penelitian Patel et al. (2011) pada sapi crossbred ditemukan jumlah koloni bakteri lebih tinggi yaitu sebesar 1,26 sampai dengan $5,90 \times 10^{4}$. Zampieri et al. (2013) melaporkan bahwa ditemukan bakteri di dalam semen beku sapi yaitu Citrobacter freundii, Enterobacter spp. (kobei, asburiae, hormaechei), Stenotrophomonas maltophilia, Enterococcus faecium, Candida parapsilosis.

Penelitian ini menemukan penurunan jumlah bakteri pada semen beku yang menggunakan antibiotik kombinasi PS dengan menggunakan antibiotik GTLS. Penggunaan antibiotik GTLS menunjukkan jumlah bakteri yang lebih rendah dibandingkan dengan kombinasi PS. Yániz et al. (2010) menyatakan bahwa PS yang digunakan dalam pengencer semen pada beberapa bakteri telah mengalami resisten sebanyak 13\%. Shin et al. (1988) melaporkan bahwa antibiotik gentamisin, 
linkomisin dan spektinomisin merupakan antibiotik broad spectrum dan lebih efektif menghambat pertumbuhan bakteri Gram positif dan Gram negatif pada semen sapi. Keberadaan bakteri yang ada di dalam semen beku dapat disebabkan pada saat semen beku diproses, dikemas dan dibekukan (Andrabi et al., 2016). Beberapa bakteri dapat survive di dalam pembekuan dan mampu bertahan hidup dalam penyimpanan pada suhu $-196^{\circ} \mathrm{C}$ (Bielanski, 2012; Tedeschi dan De Paoli, 2011).

\section{SIMPULAN}

Penelitian ini menyimpulkan bahwa pada semen segar, pengencer yang digunakan untuk pembekuan dan semen beku ditemukan bakteri yang umum terdapat pada lingkungan seperti bakteri Klebsiella sp., Micrococcus sp., dan Pediococcus sp. Enterobacter cloacae, Pseudomonas diminuta dan Serratia Enterobacter cloacae dan Serratia plymutica. Antibiotik PS dan GTLS mempunyai efektifitas yang sama dalam menghambat pertumbuhan bakteri dan tidak memengaruhi kualitas semen.

\section{SARAN}

Bakteri yang ditemukan pada penelitian ini merupakan bakteri yang umum ditemukan pada lingkungan sehingga disarankan dilakukan penelitian lebih lanjut terkait identifikasi faktor faktor yang dapat menyebabkan keberadaan bakteri bakteri tersebut selama produksi semen beku.

\section{UCAPAN TERIMA KASIH}

Penulis mengucapkan terima kasih kepada Balai Inseminasi Buatan, Lembang, Balai Besar Penelitian Veteriner, Bogor, dan Unit Reproduksi dan Rehabilitasi, Bagian Kebidanan dan Reproduksi, Departemen Klinik, Reproduksi dan Patologi, Fakultas Kedokteran Hewan, Institut Pertanian Bogor yang telah memberikan fasilitas selama penelitian ini dilaksanakan.

\section{DAFTAR PUSTAKA}

Abro SH, Abro R, Tunio MT, Rind R, Leghari RA, Khatri P, Kamboh AA. 2016. Effect of various antibiotics against the actinobacillus lignieresi, acinetobacter and citrobacter species isolated from the frozen semen of cattle. Sindh Univ Res Jour (Sci Ser) 48(2): 353-358.
Akhter S, Ansari MS, Rakha BA, Andrabi SMH, Qadeer S, Iqbal R, Ullah N. 2013. Efficiency of ciprofloxacin for bacterial control, post-thaw quality, and In vivo fertility of buffalo spermatozoa. Theriogenology 80: 378-383

Andrabi SMH, Khan LA, Shahab M. 2016. Isolation of bacteria in semen and evaluation of antibiotics in extender for cryopreservation of buffalo (Bubalus bubalis) bull spermatozoa. Andrologia 10: 1-9.

Bielanski A. 2012. A review of the risk of contamination of semen and embryos during cryopreservation and measures to limit cross-contamination during banking to prevent disease transmission in ET practices. Theriogenology 77: 467-482.

Brown GV, Schollum LM, Jarvis BDW. 1974. Microbiology of bovine semen and artificial breeding practices under New Zealand conditions. NZ J Agric Res 17: 431-442.

[BSN] Badan Standardisasi Nasional. 2017. Semen Beku-Bagian 1: Sapi. Jakarta (ID): BSN.

Cowan ST, Barrow GI, Steel KJ, Feltham RKA. 1993. Cowan and steel's manual for the identification of medical bacteria. (3rd ed.). Cambridge UK: Cambridge University Press.

[DJPKH] Direktorat Jenderal Peternakan dan Kesehatan Hewan. 2015. Laporan Tahunan; Ditjen Peternakan dan Kesehatan Hewan Tahun 2014. Jakarta. Kementerian Pertanian Republik Indonesia.

Fuquay JW, Fox PF, McSweeney PL. 2011. Encyclopedia of dairy sciences. Academic Press, UK.

Gloria A, Contri A, Wegher L, Vignola G, Dellamaria D, Carluccio A. 2014. The effects of antibiotic additions to extenders on fresh andfrozen-thawed bull semen. Anim Reprod Sci 150: 15-23.

González-Marín C, Roy R, Lüpez-Fernández C, Diez B, Carabaòo MJ, Fernández JL, Kjelland ME, Moreno JF, Gosálvez J. 2011. Bacteria in bovine semen can increase sperm DNA fragmentation rates: A kinetic experimental approach. Anim Reprod Sci 123: 139-148.

Hoyos-Marulanda V, Goularte KL, Martins KR, Voloski F, Redü JFM, Duval EH, Vieira AD, Mondadori RG, Lucia TJ. 2017. Bacterial resistance to antibiotics commonly included in extenders for cryopreserved bull semen. Anim Reprod 14(1): 225. 
Ibadin OK, Ibeh IN. 2008. Bacteriospermia and sperm quality in infertile male patient at University of Benin Teaching Hospital, Nigeria. Malay J Microbiol 4: 65-67.

[Kementan] Kementerian Pertanian. 2016. Peraturan Menteri Pertanian Republik Indonesia. Nomor 10/Permentan/Pk.210/3/ 2016 Tentang Penyediaan Dan Peredaran Semen Beku Ternak Ruminansia. Republik Indonesia.

Martin LOM, Munoz EC, De Cupere F, Van Driessche E, Echemendia-Blanco D, Rodríguez JMM, Beeckmans S. 2010. Bacterial contamination of boar semen affect the litter size. Anim Reprod Sci 12: 95104.

Meena GS, Raina VS, Gupta AK, Mohanty TK, Bhakat, Abdullah M, dan Bishist R. 2015. Effect of preputial washing on bacterial load and preservability of semen in Murrah buffalo bulls, Vet World 8(6): 798-803.

Moretti E, Capitani S, Figura N, Pammolli A, Grazia FM, Giannerini V, Collodel G. 2009. The presence of bacteria bacteria species in semen and sperm quality. J Assist Reprod Genet 26: 47-56.

Morrell JM, Wallgren M. 2014. Alternatives to antibiotics in semen extenders: a review. Pathogens 3: 934-946.

Najee HB. Al-Shawii AM, Abd- Al Rahman LY. 2012. Bacterial Contamination of Imported Bulls Frozen Semen. Al-Anbar J Vet Sci 5(1): 54-62.

Patel DY, Patel RK. 2012. Estimation of biochem-ical activities of microbial load isolated from the frozen semen of $\mathrm{HF}$ and HF crossbred cattle bulls. Curr Trends Biotechnol Pharm 6(3): 328339.

Patel HV, Patel RK, Chauhan JB. 2011. Biochemical properties of microbial load in frozen semen of cattle. Wayamba J Anim Sci 3: 117121.

Perumal P, Kumar KT, Srivastava SK. 2013. Infectious causes of infertility in buffalo bull (Bubalus bub alis). Buffalo Bull 32(2): 71 82.
Poeloengan M. 1985. Macam dan jumlah bakteria yang terdapat dalam semen pejantan sapi Brahman di Lembang, Bandung. Media Peternakan 10(1): 12-19.

Qadeer S, Batool A, Mehboob K, Ansari MS, Rakha BA, Andrabi SMH, Ullah N, Iqbal R, Akhter S. 2013. Comparison of traditional antibiotic streptomycin with neomycin, polymyxin $\mathrm{B}$, or colistin inextender for buffalo (Bubalus bubalis) bull spermatozoa. J Appl Anim Res 41(3): 289-293.

Sannat C, Nair A, Sahu SB, Sahasrabudhe SA, Kumar A, Gupta AK, Shende RK. 2015. Effect of species, breed, and age on bacterial load in bovine and bubaline semen. Vet World 8(4): 461-466.

Shin SJ, Lein DH, Patten V, Ruhnke HL. 1988. A new antibiotic combination for frozen bovine semen. 1. Control of Mycoplasmas, Ureaplasmas, Campylobacter fetus subp. venerealis and Haemophilus somnus. Theriogenology 29(3): 577-591.

Tedeschi R, De Paoli P. 2011. Collection and preservation of frozen microorganisms. Methods Mol Biol 675: 313-326.

Thieber M, Guerin B. 2000. Hygienic aspects of storage and use of semen for artificial insemination. Anim Reprod Sci 62: 233251.

Yániz JL, Marco-Aguado MA, Mateos JA, Santolaria P. 2010. Bacterial contamination of ram semen, antibiotic sensitivities, and effects on sperm quality during storage at $15{ }^{\circ} \mathrm{C}$. Anim Reprod Sci 122: $142-149$.

Zampieri D, Santos VG, Braga PA, Ferreira CR, Ballottin D, Tasic L, Basso AC, Sanches BV, Pontes JH, da Silva BP. 2013. Microorganisms in cryopreserved semen and culture media used in the in vitro production (IVP) of bovine embryos identified by matrix-assisted laser desorption ionization mass spectrometry (MALDI-MS). Theriogenology 80(4): 337-345. 
